[Bull. Agr. Chem. Soc. Japan, Vol. 22, No. 4, p. 218 227, 1958]

\title{
Studies on Amino Acids. XI.
}

\author{
Studies on the Enzymatic Resolution (IX): Acylase Activity in Yeast*
}

\author{
By Ichiro Chibata and Tsutomu Ishikawa \\ Osaka Research Laboratory, Tanabe Seiyaku Co., Ltd.**
}

Received March 10, 1958

\begin{abstract}
As a part of the studies intending to clarify biological significance of the presence of acylase, enzymatic activity which hydrolyzes acyl amino acids, its activity in yeast was investigated. As a results, the occurrence in yeast of acylase activity was confirmed for the first time.

In order to study the enzymatic properties of this acylase activity, experiments were carried out with the enzyme preparation from brewer's yeast. As a result of the investigation, yeast acylase was found to be able to hydrolyze a number of acyl amino acids, of these chloroacetyl derivatives especially readily, as in the case of previously studied acylase activity in other sources such as mold acylase. Several observations on the influence of metal ions and inhibitors, optical specificity and others were also presented.
\end{abstract}

On the acylase activity, that is, hydrolytic activity towards.acyl amino acids, Greenstein and his co-workers have made extensive studies with hog kidney acylase, by applying the enzyme for the optical resolution of amino acids.

The authors who have been studying on acylase activity in molds have reported on the practical resolution of amino acids. ${ }^{1 \sim 6)}$ Through these studies, the authors were interested in the distribution of acylase activity in various organisms and intended to clarify the biological significance of the activity. For this purpose, in succession to the previous

* Presented at the meeting of the Kansai Division of the Agricultural Chemical Society of Japan, Kyoto, April 19, 1958. * Honjo-Kawasaki-cho, Oyodo-ku, Osaka.

1) S. Yamada, I. Chibata, and S. Yamada, J. Pbam. Sor. Japan, 75, 113 (1955).

2) I. Chibata, S. Yamada, and S. Yamada, This Bulletin, 20, 174 (1956).

3) I. Chibata, A. Watanabe, and S. Yamada, This Bulletin, 21, 291 (1957).

4) I. Chibata, A. Watanabe, and S. Yamada, This Bulletin, 21, $296(1957)$.

5) I. Chibata, T. Ishikawa, and S. Yamada, This Bulletin, 21, 300 (1957).

6) I. Chibata, T. Ishikawa, and S. Yamada, This Bulletin, 21 , 304 (1957). studies on the acylase activity in Escherichease, ${ }^{7}$ the authors have preformed experiments on the acylase preparation from yeast, for no available report has appeared on this acylase activity in yeast.

\section{MATERIALS AND METHODS}

Compounds Used-The preparation of the amino acid derivatives was reported by the authors in previous papers.

Enzyme Source--Brewer's yeast employed for this experiment was generously supplied by Dr. Y. Kuroiwa, Amagasaki Laboratory, Kirin Brewing Co. The supplied yeast cells were washed with water and collected by centrifugation before they were used as enzyme source.

Extraction of Acylase Activity from YeastOn the extraction of various enzymes from yeast cells, a number of procedures have been reported. In order to find out an effective extraction method of acylase activity, the following procedures were investigated for comparison.

\section{Grinding}

Yeast $(10 \mathrm{~g})$ was ground with a little amount of quartz sand in a mortar and liquefied. After 30minutes,

7) I. Chibata, M. Kisumi, and S. Yamada, This Bulletin, 22, 24 (1958). 
M/15 phosphate buffer $(10 \mathrm{ml})$ of $\mathrm{pH} 6.0$ was added, and the mixture was kept for 12 hours and 72 hours at $5^{\circ}$. The supernatant solution obtained by centrifugation was filtered with Celite, and the filtrate was used as enzyme extracts.

\section{Autolysis with Solvents}

i) With toluene-To the yeast $(10 \mathrm{~g})$, water $(10 \mathrm{ml})$ and a little amount of toluene were added. The mixture was allowed to stand at $37^{\circ}$ for 24 hours with adjusting the $\mathrm{pH}$ to 6.0 . The extracts were prepared as the same way as in the previous case.

ii) With ethyl acetate-When ethyl acetate $(1 \mathrm{ml})$ was mixed with the yeast $(10 \mathrm{~g})$, liquefication occurred within a few minutes. After 15 minutes, water $(10 \mathrm{ml})$ was added, and the mixture was kept at $10^{\circ}$ and $37^{\circ}$ for 24 hours and 72 hours along with adjustment of the $\mathrm{pH}$ of the mixture to 6.0 and 7.0. The extracts were prepared as in the above case.

iii) With chloroform-The extracts were prepared with autolysis employing chloroform instead of ethyl acetate of the previous procedure. In this case, liquefication occurred within 5 minutes.

3. Extraction from Dried or Frozen Cells

i) Air drying (grinding with ball-mill)-Air-dried yeast was milled in a ball-mill for 10 hours at room temperature. The resulting powder (corresponding to $10 \mathrm{~g}$ of yeast) was extracted with $\mathrm{M} / 15$ phosphate buffer $(\mathrm{pH} 6.0)$ for 2 hours at $10^{\circ}$ and $37^{\circ}$.

ii) Acetone drying - The yeast $(80 \mathrm{~g})$ suspended in water $(70 \mathrm{ml})$ was added to cooled acetone $(3 \mathrm{l})$ at $-10^{\circ}$ under vigorous stirring. After a brief stirring the cells were allowed to settle, and the precipitate was filtered and washed with acetone. Evaporation of the solvent gave an acetone-dried preparation $(18.7 \mathrm{~g})$.

A portion of this acetone powder was extracted with M/15 phosphate buffer ( $\mathrm{pH}$ 6.0) for 2 hours with stirring at $10^{\circ}$ Another portion of the acetone-dried preparation was ground with quartz sand and the phosphate buffer was added. The mixture was kept for 15 hours at $5^{\circ}$ and extracted.

iii) Freezing and thawing-The yeast $(10 \mathrm{~g})$ was freezed by dry-ice and ground in a mortar. After thawing, freezing and grinding were repeated. The thawed mixture were extracted with $\mathrm{M} / 15$ phosphate buffer $(\mathrm{pH} 6.0,10 \mathrm{ml})$ by standing for 24 hours and 72 hours at $5^{\circ}$

Throughout the above mentioned procedures, the yeast was extracted with the same amount of phosphate

TABLE I

ON THE EXTRACTION OF ACTIVITy From YeAst CELlS

\begin{tabular}{|c|c|c|c|c|c|c|}
\hline \multicolumn{3}{|r|}{ Procedure } & $\mathrm{pH}$ & $\begin{array}{l}\text { temperature } \\
\left({ }^{\circ} \mathbf{C}\right)\end{array}$ & hours & $\begin{array}{l}\text { increased } \\
\text { O. D. }\end{array}$ \\
\hline \multirow[t]{2}{*}{1} & & Grinding with quartz sand & 6.0 & 5 & 12 & 118 \\
\hline & & $\prime \prime$ & 6.0 & 5 & 72 & 259 \\
\hline \multirow[t]{11}{*}{2} & i) & Autolysis with toluene & 6.0 & 37 & 24 & 98 \\
\hline & ii) & Autolysis with ethyl acetate & 7.0 & 37 & 24 & 30 \\
\hline & & $\prime \prime$ & 6.0 & 10 & 24 & 101 \\
\hline & & $\prime \prime$ & 7.0 & 10 & 24 & 100 \\
\hline & & $\prime \prime$ & 7.0 & 37 & 72 & 79 \\
\hline & & $\prime \prime$ & 6.0 & 10 & 72 & 99 \\
\hline & & $\prime \prime$ & 7.0 & 10 & 72 & 109 \\
\hline & iii) & Autolysis with chloroform & 7.0 & 37 & 24 & 21 \\
\hline & & $\prime \prime$ & 6.0 & 10 & 24 & 117 \\
\hline & & $\prime \prime$ & 7.0 & 37 & 72 & 286 \\
\hline & & $\prime \prime$ & 6.0 & 10 & 72 & 279 \\
\hline \multirow[t]{6}{*}{3} & i) & $\begin{array}{l}\text { Air drying and grinding } \\
\text { with ball will }\end{array}$ & 6.0 & 37 & 2 & 385 \\
\hline & & 11 & 6.0 & 10 & 2 & 355 \\
\hline & ii) & Acetone drying & 6.0 & 10 & 2 & 66 \\
\hline & & // (with grinding) & 6.0 & 5 & 15 & 270 \\
\hline & iii) & Freezing and thawing & 6.0 & 5 & 24 & 346 \\
\hline & & "l & 6.0 & 5 & 72 & 335 \\
\hline
\end{tabular}

The incubation mixture contained $1 \mathrm{ml}$ of $0.05 \mathrm{M}$ chloroacetyl-pL-methionine solution, $1 \mathrm{ml}$ of ten-times diluted extracts and $1 \mathrm{ml}$ of $\mathrm{M} / 15$ phosphate buffer $(\mathrm{pH} 6.0)$. The mixture was incubated at $37^{\circ}$ for 24 hours. The liberated amino acid was determined by colorimetric ninhydrin method and the extent of reaction was expressed by increased $O$. D. for the comparison of extraction procedure. 
buffer or water. The obtained extracts were diluted ten-times by volume and their hydrolytic activity was assayed by employing chloroacetylmethionine as the substrate. The results obtained are shown in Table I.

As indicated in the Table, grinding of air-dried yeast in a ball-mill, extraction by freezing and thawing, and autolysis by chloroform were found to be effective extraction procedures.

Enzyme Preparation-As the extraction procedure of acylase activity from yeast cells was investigated, preliminary experiments of purification of acylase activity from these extracts obtained by the above procedures, were performed for the purpose of obtaining a stable enzyme preparation.

Although the extracts obtained by freezing and thawing procedure and by ball-mill procedure showed high activity, these extracts were not so suitable for purification as the obstructive turbidity and viscosity. So, by employing the procedure of plasmolysis with chloroform, more suitable conditions for the enzyme preparation were investigated.

The yeast $(20 \mathrm{~g})$ was mixed with chloroform $(2 \mathrm{ml})$ and liquified. The mixture was extracted with $\mathrm{M} / 30$ phosphate buffer ( $\mathrm{pH} 6.0,20 \mathrm{ml}$ ) or with 0.4 saturated aqueous ammonium sulfate $(\mathrm{pH} 6.0,20 \mathrm{ml})$ by keeping for 96 hours at $5^{\circ}$ along with adjusting the $\mathrm{pH}$ to 6.0 . In the other run, after liquefication, the same amount of water was added, stirred for 1 hour, and colored initial autolysate was removed by centrifugation. To the precipitate, chloroform $(1 \mathrm{ml})$ and 0.4 saturated aqueous ammonium sulfate $(\mathrm{pH} 6.0,20 \mathrm{ml})$ were added and extracted just as described in the above case. Activity of these extracts was assayed for comparison after they were dialyzed against chilled water under the some conditions.

As indicated in Table II, extraction with aqueous ammonium sulfate was much more effective than ordinary extraction with phosphate buffer, especially the process removing the colored initial autolysate gave a clear extract, which is suitable for enzyme preparation. So with this procedure, preparation of yeast acylase was carried out as follows: Brewer's yeast $(1 \mathrm{~kg})$ was mixed with chloroform $(100 \mathrm{ml})$ for liquefication. After it was liquified, water (11) was added and the mixture was kept for 1 hour at $10^{\circ}$ with occasional stirring. A colored supernatant solution was removed by centrifugation. To the separated precipitate, chloroform $(50 \mathrm{ml})$ and 0.4 saturated aqueous ammonium sulfate $(\mathrm{pH} 6.0,11)$ were added. For further autolysis, the mixture was allowed to stand for 96 hours at $10^{\circ}$ with occasional adjustment of the $\mathrm{pH}$ to 6.0. Centrifugation gave a clear supernatant solution $(1050 \mathrm{ml})$, which was used as the extract (1-C in Table II). 'To this extract, ammonium sulfate was added to 0.75 saturation at $\mathrm{pH} 6.0$. The resulting precipitate was collected and dissolved in $\mathbf{M} / 30$ phosphate buffer (pH 6.0, $500 \mathrm{ml}$ ). The solution obtained was treated with ammonium sulfate, the precipitate resulting from 0.45 saturation was removed by centrifugation and discarded. The supernatant solution was brought up to 0.7 saturation with ammonium sulfate, and the resulting precipitate was collected with centrifugation. Then the precipitate was dissolved in $\mathrm{M} / 30$ phosphate buffer ( $\mathrm{pH} \mathrm{6.0)}$ and dialyzed against chilled water for 2 days. The precipitate formed during dialysis was removed by centrifugation. Then, to the supernatant solution $(265 \mathrm{ml}, 2$ in Table II), acetone (33\% by volume), previously chilled to $-5^{\circ}$, was added with stirring. The precipitate was collected by centrifugation and dissolved in M/30 phosphate buffer ( $\mathrm{pH} \mathrm{6.0)}$. A small amount of insoluble material was removed by centrifugation, and the clear supernatant solution was lyophylyzed. The obtained white powder weighed $4.6 \mathrm{~g}$ ( 3 in Table II), its yield of total activity being

TABLE II

Extraction AND PURIfication of YeAst ACyLase

\begin{tabular}{|c|c|c|c|c|}
\hline \multirow{4}{*}{$\begin{array}{c}\text { Extraction } \\
\text { Process }\end{array}$} & & Procedures & $\begin{array}{l}\text { Acylase activity } \\
\mu \mathrm{M} / \mathrm{hr} / \text { Prot. } \mathrm{N} \mathrm{mg}\end{array}$ & $\begin{array}{c}\text { Total activity } \\
\mu \mathrm{M}\end{array}$ \\
\hline & $1-\mathbf{a}$ & Phosphate buffer & 22.2 & 992 \\
\hline & $1-b$ & 0.4 saturated ammonium sulfate solution & 45.0 & 2480 \\
\hline & $1-\mathrm{c}$ & The same as $1-b$ except removing initial autolysate & 52.3 & 2453 \\
\hline \multirow{3}{*}{$\begin{array}{l}\text { Purification } \\
\text { Process }\end{array}$} & $1-c$ & The extracts Prepared by $1-c$ & 58.6 & 124200 \\
\hline & 2 & Ammonium Sulfate fraction and dialysis & 75.2 & 113000 \\
\hline & 3 & Acetone fractionation and lyophylization & 235.0 & 73000 \\
\hline
\end{tabular}


$59 \%$ of the extract.

This preparation was stable for at least several months in a desicator kept in a cool place.

Standard Enzyme Reaction-Enzyme reaction was carried out by incubating digests composed of $1 \mathrm{ml}$ of $0.025 \mathrm{M}$ substrate solution $(0.05 \mathrm{M}$ for racemic compounds), $1 \mathrm{ml}$ of enzyme solution and $1 \mathrm{ml}$ of $\mathrm{M} / 15$ phosphate buffer (at appropriate $\mathrm{pH}$, described in Table III) at $37^{\prime}$ for 2 hours, unless otherwise stated. Liberated amino acids were measured by the colorimetric ninhydrin method, and expressed by per cent hydrolysis of the susceptible L-isomers. (The rate of hydrolysis was determined from the splitting of the susceptible substrate which was between 10 to 30 per cent).

For example, the effect of enzyme concentration on the rate of hydrolysis of acetyl-DL-methionine under standard conditions, is shown in Fig. 1.

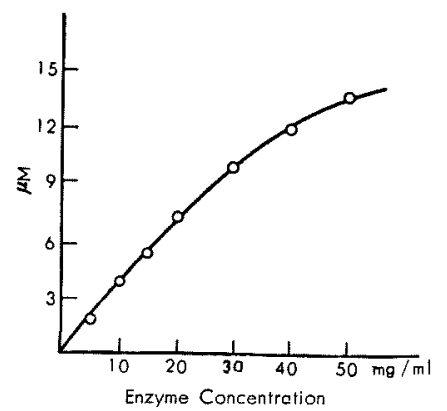

Fig. 1. Effect of Enzyme Concentration on Reaction Rate.

The mixture containing varying amount of enzyme and acetyl-DL-methionine was incubated at $\mathrm{pH} 6.0$ for 2 hours under standard conditions.

\section{RESULTS}

Effect of pH and Buffers In a previous paper ${ }^{6}$, the authors observed that the optimal $\mathrm{pH}$ towards acetyl and chloroacetyl derivatives differed in case of fungal acylase preparation. Then, the effect of $\mathrm{pH}$ on the hydrolytic rate of various acyl acids by the yeast acylase preparation was studied and the optimal $\mathrm{pH}$ was determined. The results obtained are summarized in Table III.

Although $\mathrm{pH}$ optima for the acyl derivatives of monoaminodicarboxylic acids such as aspartic acid and glutamic acid seemed to be
TABLE III

OPTIMAL $_{\mathrm{pH}}$ FOR THE HYDROLYSIS OF ACYL AMINO ACIDS

\begin{tabular}{|c|c|c|}
\hline Acyl derivs. & Acetyl & Chloroacetyl \\
\hline Alanine & 6.5 & 6.5 \\
\hline Leucine & 6.5 & 6.0 \\
\hline Methionine & 6.3 & 6.0 \\
\hline Glutamic acid & 5.0 & 5.0 \\
\hline Aspartic acid & 5.5 & 5.0 \\
\hline$\varepsilon$-Benzoyllysine & 6.5 & 6.5 \\
\hline Tryptophan & 7.0 & 6.5 \\
\hline Phenylalanine & 6.5 & 6.3 \\
\hline Tyrosine & & 6.5 \\
\hline Glycylglycine & \multicolumn{2}{|c|}{7.8} \\
\hline Glycylmethionine & \multicolumn{2}{|c|}{7.5} \\
\hline
\end{tabular}

on the acidic-side, optimal $\mathrm{pH}$ of other acyl amino acids were around $6.0 \sim 6.5$, no appriciable difference of optimal $\mathrm{pH}$ between acetyl and chloroacetyl derivatives being detected.

Besides acyl amino acids, optimal pH for the hydrolsis of dipeptides such as glycylglycine and glycylmethionine by this yeast preparation was also studied and it was found to be on the alkaline-side.

For the purpose of investigation of the influence of buffers, a number of other buffers, including Walpole acetate buffer, Michaelis Veronal buffer, and Sörensen citrate buffer, were tested as substitutes for Sörensen phosphate buffer. Acetylmethionine, chloroacetylmethionine, chloroacetylphenylalanine and chloroacetylglutamic acid were employed as the substrates, and conditions were standard except for the buffers. The $\mathrm{pH}$-activity curves obtained are presented in Fig. 2.

A different $\mathrm{pH}$ optimum was found for each of the buffers, as well as a difference in the amount of hydrolysis took place. Veronal buffer permitted highest reaction rate so far as the acyl amino acids employed in this experiment, and citrate buffer was apparently inhibitory to the acylase activity.

In the case of Veronal buffer, optimal $\mathrm{pH}$ appreciably shifted to the acidic-side and the highest activity for the hydrolysis of acyl derivatives of neutral amino acids was observ- 

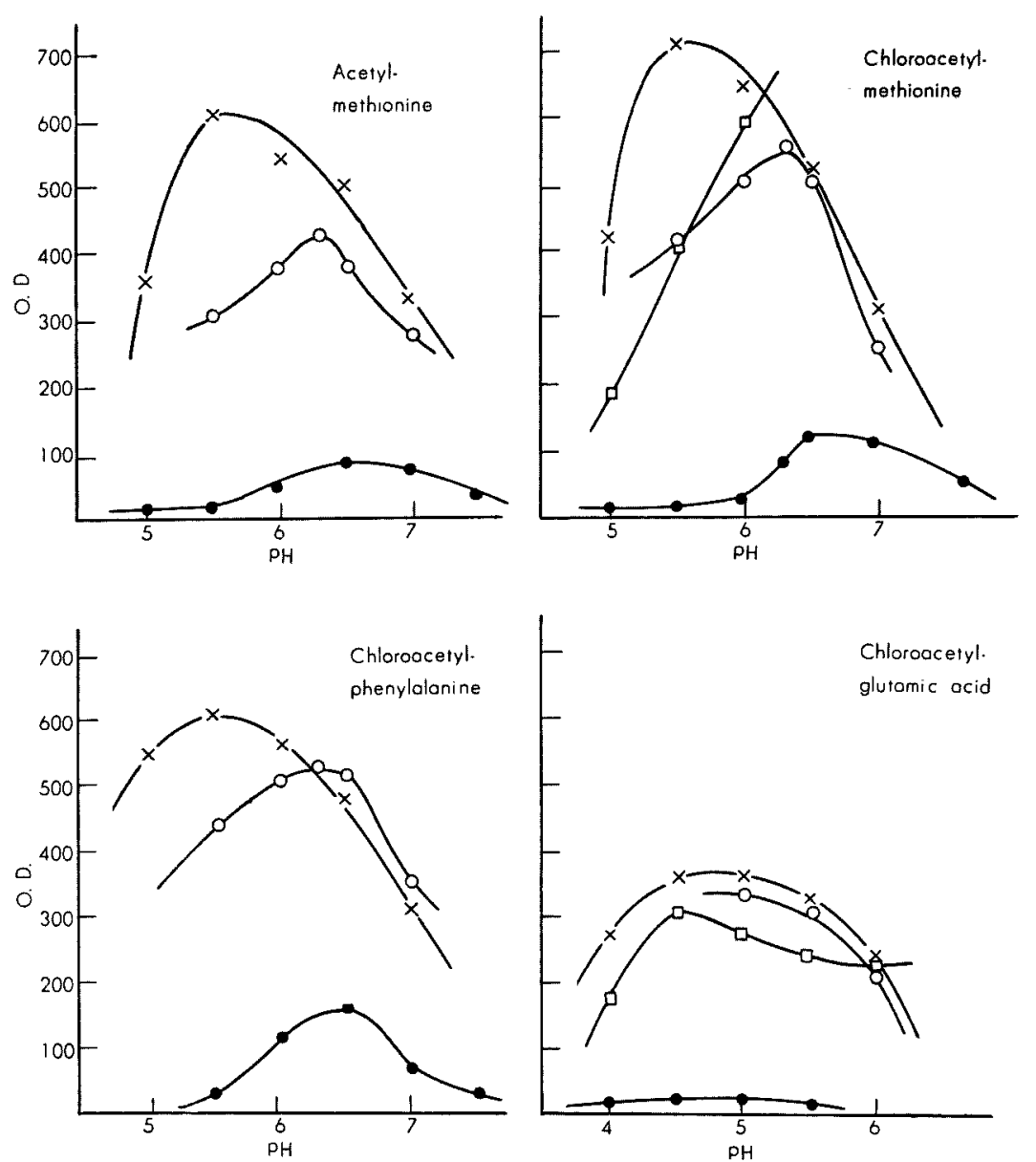

FIG. 2. pH-Activity Gurves for Yeast Acylase Preparation in Individual Buffer Solutions.

The assay was made under standard conditions except for the buffer utilized. The symbols represent phosphate $(O-O)$, Veronal $(x-x)$, acetate $(\square-\square)$, and citrate $(--)$ ) buffers.

ed around $\mathrm{pH}$ 5.5.

The results indicate the need for specifying exactly the type of buffer used in the determination of yeast acylase activity.

Susceptibility of Acyl Amino Acids The susceptibility of the various acyl amino acids towards the yeast acylase preparation was studied in the initial rates of hydrolysis under standard conditions. The results obtained are shown in Table IV, in which the rates of hydrolysis were converted to relative suscep- tibility taking that of acetylmethionine as 100 for convenience of interpreting the results.

As in the case of mold acylase ${ }^{6)}$ previously studied, a number of acyl amino acids could be hydrolyzed by this yeast acylase preparation. Aliphatic acyl amino acids, such as acetylmethionine, chloroacetyl derivatives of alanine and leucine, were readily hydrolyzed. As for the acyl derivatives of aromatic amino acids, although chloroacetyl derivatives of phenylalanine and tyrosine were very suscep- 
TABLE IV

Relative SUSCEPTIBILITy of ACyl Amino ACIDS TO THE YeAst ACYLASE

PREPARATION

Acyl amino acids

Glyc-Glycine

Susceptibility

Ac-Alanine

23

Clac- "I

Ac-Leucine

Clac- " "

Ac-Methionine

Clac- "

Glyc- " "

Ac-Glutamic acid

Clac- "

Ac-Aspartic acid

Clac- "

$\varepsilon-\mathrm{Bz}-\alpha-$ Ac-Lysine

$\varepsilon-\mathrm{Bz}-\alpha$-Glac- "

Ac-Tryptophan

Clac- "

Ac-Phenylalanine

Clac- " "

Clac-Tyrosine
Lineweaver and Burk $^{8)}$ for the determination of a $\mathrm{Km}$ value. As shown in Fig. 3, the substrate concentration giving half maximal velocity, i.e., $\mathrm{Km}$ was calculated to be around $8.3 \times 10^{-3} \mathrm{M}$.

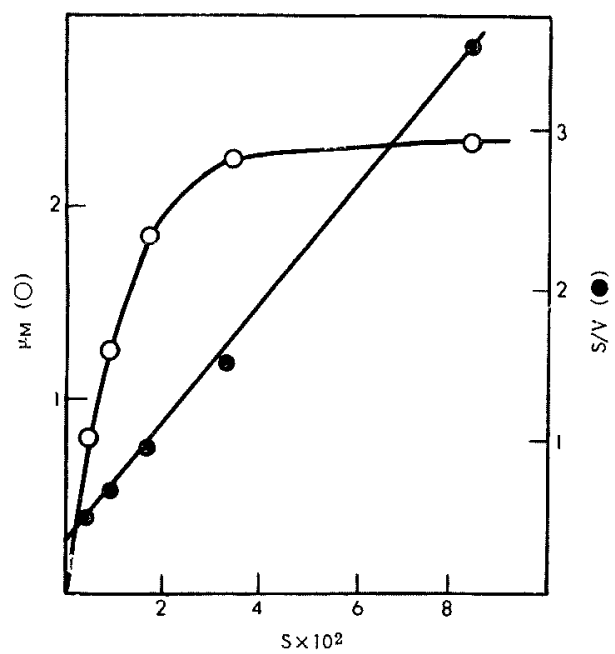

FIG. 3. Effect of the Concentration of Acetylmethionine to the Reaction Rate.

The reaction was similar to the standard condition except the varying substrate concentrations, and the incubation was carried out for 1.5 hours.

Effect of Metals and Inhibitors It had been observed that funga ${ }^{3,4)}$ and bacterial acylase ${ }^{7)}$ preparations were activated by cobalt ion. Hence in order to study the effect of metals and inhibitors to the yeast acylase activity, acetyl and chloroacetyl methionines, and chloroacetylphenylanine were employed as substrates, and various divalent metal ions (metal chlorides), metal binders, and sulfhydryl reagents were added to the enzyme assay. Effect on the hydrolysis of glycylglycine and glycylmethionine was also investigated for comparison.

The results, showed in Table $\mathrm{V}$, revealed that the effect towards glycylmethionine and all the acyl amino acids tested were almost identical except the effect on the hydrolysis of glycylglycine. Namely, although salts of 8) H. Lineweaver and D. Butk, J.Am. Cbem. Sor., 56, 658 (1934). 
TABLE V

EFFect of Metals and InHIBIToRs on THE ENZyme ACTIVITY

\begin{tabular}{|c|c|c|c|c|c|c|}
\hline $\begin{array}{c}\text { Additions } \\
\text { none }\end{array}$ & $\begin{array}{c}\text { Conc. } \\
\text { (M) }\end{array}$ & $\begin{array}{c}\text { Acetyl- } \\
\text { methionine } \\
100\end{array}$ & $\begin{array}{c}\text { Chloroacetyl- } \\
\text { methionine } \\
100\end{array}$ & $\begin{array}{l}\text { Chloroacetyl- } \\
\text { phenylalanine } \\
100\end{array}$ & $\begin{array}{c}\text { Glycyl- } \\
\text { methionine } \\
100\end{array}$ & $\begin{array}{l}\text { Glycyl- } \\
\text { glycine } \\
100\end{array}$ \\
\hline $\mathrm{Cu}$ & $10^{-3}$ & 7 & 5 & 2 & 23 & 17 \\
\hline $\mathrm{Mg}$ & $\left\{\begin{array}{l}10^{-2} \\
10^{-3} \\
10^{-4}\end{array}\right.$ & $\begin{array}{l}89 \\
99 \\
98\end{array}$ & $\begin{array}{l}96 \\
90 \\
89\end{array}$ & $\begin{array}{l}107 \\
103 \\
103\end{array}$ & 93 & 97 \\
\hline $\mathrm{Ca}$ & $10^{-3}$ & 96 & 83 & 96 & 23 & 40 \\
\hline $\mathrm{Zn}$ & $\left\{\begin{array}{l}10^{-2} \\
10^{-3} \\
10^{-4}\end{array}\right.$ & $\begin{array}{l}37 \\
71 \\
85\end{array}$ & $\begin{array}{l}68 \\
75 \\
98\end{array}$ & $\begin{array}{l}19 \\
72 \\
82\end{array}$ & 68 & 45 \\
\hline $\mathrm{Mn}$ & $\left\{\begin{array}{l}10^{-2} \\
10^{-3} \\
10^{-4}\end{array}\right.$ & $\begin{array}{l}12 \\
15 \\
32\end{array}$ & $\begin{array}{l}11 \\
12 \\
70\end{array}$ & $\begin{array}{r}4 \\
13 \\
17\end{array}$ & 72 & 110 \\
\hline $\mathrm{Fe}$ & $10^{-๖}$ & 6 & 4 & 6 & 3 & 54 \\
\hline Co & $\left\{\begin{array}{l}10^{-2} \\
10^{-8} \\
10^{-4}\end{array}\right.$ & $\begin{array}{r}9 \\
85 \\
92\end{array}$ & $\begin{array}{r}5 \\
65 \\
92\end{array}$ & $\begin{array}{r}3 \\
81 \\
102\end{array}$ & $\begin{array}{l}48 \\
98\end{array}$ & 680 \\
\hline $\mathrm{Ni}$ & $10^{-3}$ & 22 & 8 & 14 & 52 & 125 \\
\hline $\mathrm{NaF}$ & $10^{-3}$ & 102 & 97 & 96 & 99 & 84 \\
\hline EDTA & $\left\{\begin{array}{l}10^{-3} \\
10^{-4} \\
10^{-3} \\
10^{-6}\end{array}\right.$ & $\begin{array}{r}5 \\
7 \\
15 \\
100\end{array}$ & 3 & 5 & 2 & 4 \\
\hline $\mathrm{NaCN}$ & $10^{-\ddot{b}}$ & 110 & 102 & 101 & 104 & 86 \\
\hline PCMB & $10^{-3}$ & 6 & 6 & 5 & 28 & 63 \\
\hline Iodoacetate & $10^{-3}$ & 91 & 85 & 87 & 63 & 93 \\
\hline
\end{tabular}

magnesium and calcium at the concentration tested, slightly affected the reaction, salts of copper, manganese, nickel, and iron were apparently inhibitory. Also, cobalt which was the activator for fungal and bacterial acylases and zinc were found slightly inhibitory. Despite this, any metal ion stimulating acylase activity of the yeast preparation could not be found under the conditions employed.

In the case of hydrolysis of glycylglycine, calcium was also proved inhibitory besides the salts of copper, zinc, and iron. Although cobalt, nickel and manganese ions were inhibitory to acylase activity, apparent stimulation was obtained with cobaltous ion, and salts of manganese and nickel also showed an enhancing effect though slightly on the hydrolysis of glycylglycine.

Marked inhibition by the metal chealating agent, ethylenediaminetetraacetic acid (EDTA) was observed in all the substrates tested. In the case of sulfhydryl reagents, although the inhibitory effect of iodoacetate appeared to a less extent, $p$-chloromercuribenzoate markedly inhibited the acylase activity. These results indicate that metal ion and sulfhydryl group play a certain role in the action of the yeast acylase.

For further study on the relation between the enzyme action and metal ion, the experiment was carried out with EDTA treated enzyme so as to investigate the reactivation by metal ions. The enzyme was treated with a $10^{-4} \mathrm{M}$ concentration of EDTA at $37^{\circ}$ for 30 minutes, which abolished almost all the activity. To this enzyme solution, $1.1 \times 10^{-3} \mathrm{M}$ concentration of metal chlorides were added and it was preincubated at $37^{\circ}$ for 30 minutes. With this enzyme solution, activity was determined by employing acetylmethionine, glycyl- 
TABLE VI

Reactivation of THE INACTIVATED ENzyme by Metal IONS.

\begin{tabular}{|c|c|c|c|c|c|c|c|c|c|c|}
\hline \multirow{2}{*}{ Substrate } & \multirow{2}{*}{$\underset{\text { treatment }}{\text { EDTA }}$} & \multicolumn{9}{|c|}{ Activity in the Presence of Ions } \\
\hline & & None & $\mathrm{Cu}$ & $\mathrm{Mg}$ & $\mathrm{Ca}$ & $\mathrm{Zn}$ & $\mathrm{Mn}$ & $\mathrm{Fe}$ & Co & $\widehat{\mathrm{Ni}}$ \\
\hline \multirow{2}{*}{$\begin{array}{l}\text { Acetyl- } \\
\text { methionine }\end{array}$} & fnone & 100 & 7 & 99 & 96 & 71 & 15 & 6 & 85 & 22 \\
\hline & \{treated & 0 & 0 & 0 & 0 & 59 & 0 & 4 & 18 & 4 \\
\hline \multirow{2}{*}{$\begin{array}{l}\text { Glycyl- } \\
\text { methionine }\end{array}$} & gnone & 100 & 23 & 93 & 15 & 68 & 72 & 3 & 48 & 52 \\
\hline & $\{$ treated & 0 & 4 & 0 & 0 & 18 & 28 & 0 & 16 & 13 \\
\hline \multirow{2}{*}{$\begin{array}{l}\text { Glycyl- } \\
\text { glycine }\end{array}$} & fnone & 100 & 17 & 97 & 6 & 45 & 110 & 54 & 680 & 125 \\
\hline & $\{$ treated & 10 & 22 & 12 & 4 & 24 & 50 & 40 & 137 & 36 \\
\hline
\end{tabular}

The enzyme assay was carried oue under standard conditions except for the preincubation of EDTA treated enzyme solution with metal ions. The activity of the respective substrate without EDTA treatment and none addition of metal ions was taken as control 100 .

methionine and glycylglycine as the substrates. Activity was represented as the percentage of the control without EDTA treatment for comparison.

As shown in Table VI, although only partial reactivation was recognized, complete reactivation as observed in the case of mold acylase, ${ }^{3)}$ was not attained under such conditions employed.

Effect of Temperature For the purpose of studying on the effect of temperature to the enzyme reaction, the extent of hydrolysis of acetyl-, chloroacetylmethionines and chloroacetylphenylalanine was determined at respective optimal $\mathrm{pH}$

FIG. 4. Effect of Time and Temperature on the Hydrolysis by the Enzyme Preparation from Brewer's Yeast.

The enzyme assay was carried out under standard conditions modified by varying incubation terms and temperature.
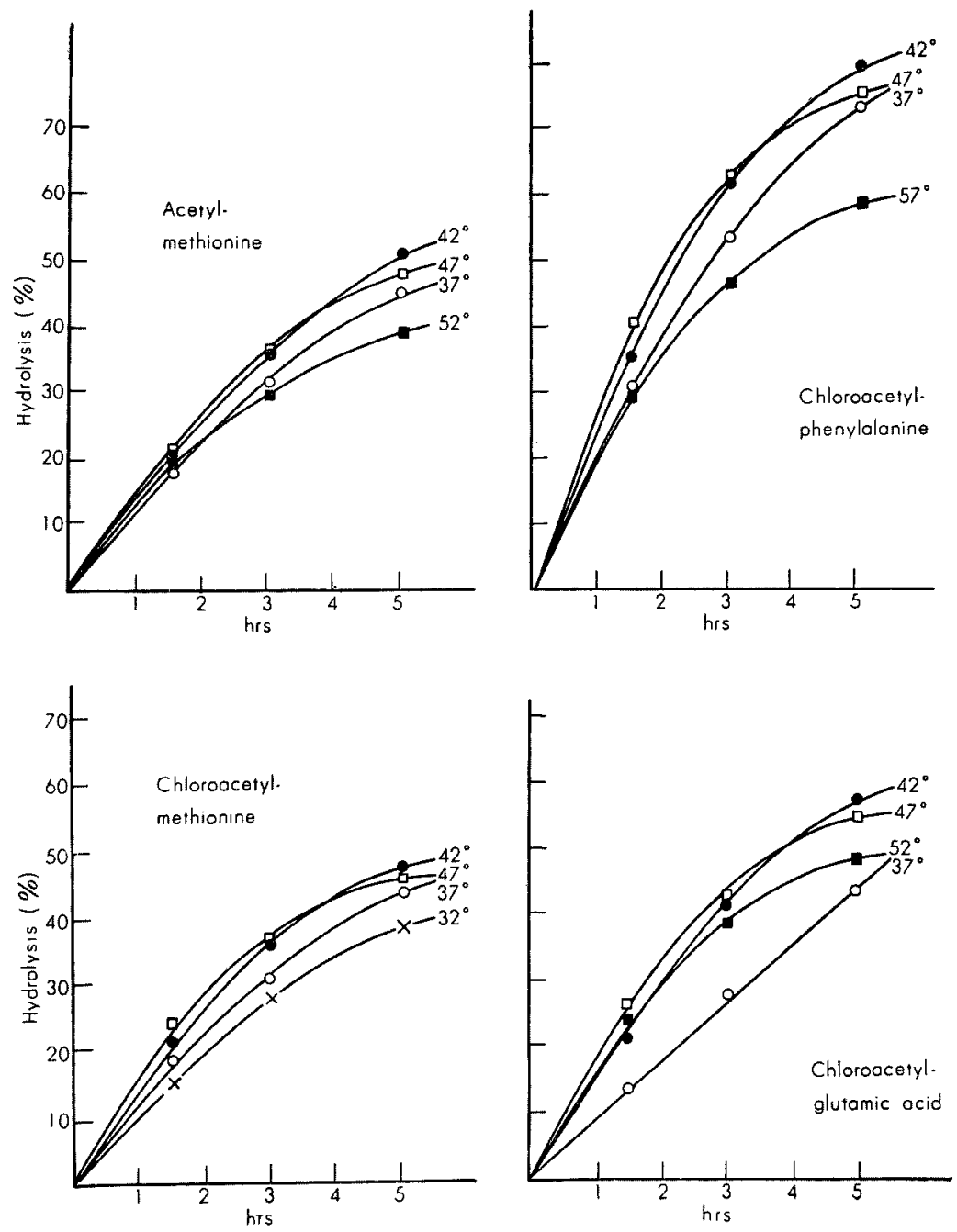
and varied temperature instead of at $37^{\circ}$ as in standard conditions. The results, indicated in Fig. 4, disclosed that maximal rate of hydrolysis was observed at $47^{\circ}$ within 3 hours in all of the substrates tested.

Optical Specificity Optical specificity of this acylase preparation from yeast was investigated, since some of the bacterial enzymes had been known to act on $\mathrm{D}$-amino acid derivatives. The enzymatic reaction employing $0.025 \mathrm{M}$ chloroacetyl-L-methionine and $0.05 \mathrm{M}$ chloroacetyl-DL-methionine, as the substrate was simultaneously carried out under standard conditions, and the extent of hydrolysis was

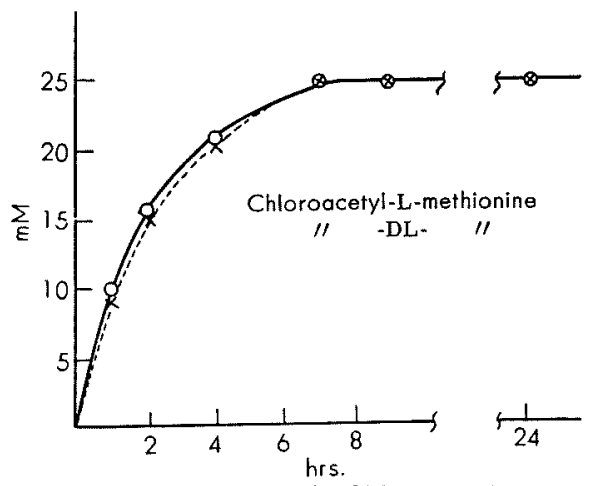

FIG. 5. Hydrolysis of Chloroacetyl-L- and Chloroacetyl-DL-methionines by the Yeast Acylase Preparation.

The enzymatic reaction employing $0.025 \mathrm{M}$ chloroacetyl$\mathrm{L}$-methionine and $0.05 \mathrm{M}$ chloroacetyl-DL-methionine carried out at $\mathrm{pH} 6.0$ under standard conditions. Rate of hydrolysis is expressed by the liberated amount of amino acid.

determined. As indicated in Fig. 5, in either case, the reaction stopped at the cleavage of $25 \mathrm{~mm}$ of the substrate, that is, $100 \%$ hydrolysis of the L-form substrate and $50 \%$ hydrolysis of the racemic substrate, in which no further hydrolysis was occurred by prolonged incubation. This result indicates that the yeast preparation is optically specific and acts only to the L-form of acyl amino acid and not on the D-isomer. While, on the other hand it appears that the presence of D-isomer does not appriciably affect the rate of hydrolysis of the acyl-L-amino acid within the sensitivity of the method employed.

\section{DISCUSSION}

The authors' studies performed on the characteristics of the yeast acylase preparation obtained from brewer's yeast reveal that the preparation resembles other acylase preparations such as fungal and bacterial acylases in several features. The yeast preparation is able to hydrolyze acyl derivatives of various types of aliphatic and aromatic amino acids such as mold acylase, previously studied by the authors. Namely, a callyl amino acids tested were hydrolyzed more or less with the preparation, and chloroacetyl derivatives were more susceptible than the acetyl derivatives. Futhermore optical specificity is also similar to other acylases previously studied, the Lform of acyl amino acids is selectively hydrolyzed. These results indicate that the yeast acylase preparation may be used for the purpose of enzymatic resolution of racemic amino acids.

The inhibitions by EDTA and PCMB indicates that a metal ion and sulfhydryl group play a role in this enzyme action. Although the acylase preparations from other sources were activated by cobaltous ion, any appreciable stimulation was not observed by the addition of divalent metal ions including cobalt in the yeast preparation under the conditions employed. Also, the enzyme previously treated with EDTA was not appreciably reactivated with divalent metal ions. These facts may be apprehended that the enzyme is irreversibly denaturated by EDTA treatment or the enzyme requires other metal ions than the divalent metal ions tested.

Besides acyl amino acids, the yeast preparation employed can hydrolyzed glycylmethionine readily and glycylglycine in a slow rate. In this study, no attempt was made to separate the acylase activity from dipeptidase activity. Although, the influence of metal ions towards acyl amino acids and glycylmethionine appeared to be almost the same, the effect to 
hydrolysis of glycylglycine differed. For instance, the latter was activated with cobalt ion but the others were rather inhibited with the ion. However, it can not be decided from the above fact whether this peptidase action especially to glycylglycine, is due to a different enzyme than acylase at the present state of investigation. It is also possible that the veast preparation contains several enzymes which are capable of hydrolyzing acyl amino acids, so the decision as to whether or not the acylase activity in this enzyme preparation is due to the occurrence of single or more specific acylases has to be held until the enzyme is obtained in a further purified state.
Through the present studies, the occurrence in yeast of acylase activity has been confirmed for the first time, and disclosing some enzymatic properties. The authors intend to continue the studies in order to clarify the biological significance of acylase activity occurring in various organisms.

Acknowledgements The authors are grateful to Prof. H. Mitsuda of Kyoto University, Dr. M. Fujisawa of this Laboratory, and Dr. S. Yamada of Tokyo Research Laboratory for their helpful advice and encouragement. They are also indebted to Dr. Y. Kuroiwa, Amagasaki Laboratory, Kirin Brewing Co. for generously supplying the yeast used in this work.

[Bull. Agr. Chem. Soc. Japan, Vol. 22, No. 4, p. 227 233, 1958]

\title{
Studies on Phenolic Lactones
}

\section{Part I. Synthesis of $\alpha$-Piperonylidene- $\beta$-piperonyl-butyrolactone}

\author{
By Kyôhei Yamashita and Masanao Matsui \\ Faculty of Agriculture, University of Tokyo
}

Received March 28, 1958

\begin{abstract}
Condensation of piperonal with diethyl piperonylsuccinate afforded $\alpha$-(3,4-methylenedioxyphenyl-hydroxymethyl)- $\beta-\left(3,4\right.$-methylenedioxybenzyl)-succinic acid, m.p. $173 \sim 5^{\circ} \mathrm{C}$. Dehydration with $p$-toluenesulfonic acid or acetic anhydride gave two kinds of $\alpha$-piperonylidene- $\beta$-piperonyl succinic anhydrides, m.p. $167-8^{\circ} \mathrm{C}$ and $115-7^{\circ} \mathrm{C}$, respectively. Reduction of a-piperonylidene$\beta$-piperonyl-succinic acid thioethyl methyl ester by Raney Ni catalyst followed by saponification and lactonization afforded $\alpha, \beta$-dipiperonyl butyrolactone, m.p. $107 \sim 8^{\circ} \mathrm{C}$, and a small amount of $\alpha$-piperonylidene- $\beta$-piperonyl-butyrolactone, m.p. $154 \sim 5.5^{\circ} \mathrm{C}$.
\end{abstract}

Hibalactone is the neutral component isolated from dried leaves of Chamaecyparis obtusa Sieb et Zucc by Masumura. ${ }^{11}$ Catalytic hy-

1) M. Masumura, Bull. Chem. Sor. Japan, 76, 423 (1955). drogenation of this substance affords isoninokinin, ${ }^{2)}$ which is converted into hinokinin by base catalyzed isomerization. The ultraviolet ${ }^{22}$ 